\title{
Srećko Badurina (1930. - 1996.), biskup trećoredac, svjedok vjere i znak vremena
}

\begin{abstract}
Autor u ovom radu obrađuje lik Srećka Badurine (1930. - 1996.), biskupa trećoreca, koji je ostavio vrlo dubok trag kao franjevac trećoredac i kasnije kao šibenski biskup. Rad je podijeljen na tri dijela. U provome se dijelu u osnovnim konturama opisuje životni put biskupa Srećka, kako bi ga se postavilo u ispravan povijesni okvir unutar kojega će se propitivati važnost i značenje njegova svjedočanstva. Potom se u drugome dijelu, polazeći od konteksta povijesnih okolnosti, jasnije ističe njegova važnost kao vjerodostojnog svjedoka vjere u drugoj polovini 20. stoljeća, stavljajući osobit naglasak na njegove stavove prema komunizmu u razdoblju do 1990., kao i na vrlo razborit i krepostan stav u delikatnim okolnostima Domovinskog rata. Upravo zato što je bio svjedok vjere, postao je znakom svoga vremena, o čemu je riječ u trećem dijelu. Posebice se propituje recepcija Drugog vatikanskog sabora mons. Badurine, kao i način iščitavanja ostalih znakova vremena u kojemu je živio (redovništvo, ateizam, mirotvorstvo).
\end{abstract}

\section{Uvod}

Sukladno s naslovom, temu bih razradio u tri dijela, koja međusobno upućuju jedan na drugi te se također neizostavno isprepleću u jednoj osobi, a to je biskup Srećko Badurina, kojem je posvećen ovaj rad. ${ }^{1} \mathrm{U}$ prvom dijelu najprije valja u kratkim crtama ocrtati životni put biskupa Srećka, a potom progovoriti i o dvjema tematskim cjelinama. Napose se treba osvrnuti na ulogu biskupa Srećka kao čovjeka vjere, uronjenog u vrijeme u kojem je živio, svjesno inzistirajući na tim dvama ključnim pojmovima u kojima se može prepoznati njegova osoba i djelovanje, koje je nama dostupno iz izravnih spisa i još svježih svjedočanstava o njemu. No, bez obzira na naslov koji je definiran na taj način, o biskupu Srećku može se govoriti u pravom smislu riječi kao o znaku i svjedoku vjere, kao i o znaku i svjedoku vremena jer je ostavio dubok trag u razdoblju u kojem je živio na mjestu i u službama koje mu je Gospodin povjerio.

Radi se o prvom franjevcu trećorecu glagoljašu iz Hrvatske koji je postao biskupom (usp. BADURINA 2012: 334). 


\section{Životni put biskupa Srećka}

No, prije nego što prijeđemo na središnju temu, neophodno je iznijeti vremenski okvir, odnosno opisati životni put biskupa Srećka. Srećko Badurina rođen je 12. svibnja 1930. u Lunu na otoku Pagu kao prvijenac od jedanaestoro braće i sestara, čiji su roditelji bili Pavao i Sokola. Prve redovničke zavjete položio je 1947., studij teologije završio je u Splitu, a za svećenika je zaređen 29. lipnja 1955. u Zadru. Nakon što je godinu dana bio župni vikar u Župi sv. Ivana Krstitelja u Zadru, u Zagrebu je nastavio teološki studij, koji je okrunio obranom doktorata s temom „Svrha braka osobito po nauci Pija XII.“ (prosinac 1965.), nakon čega je bio i na dvogodišnjoj specijalizaciji u Rimu i Louvenu (1966. - 1968.). Stekavši prikladnu naobrazbu, počeo je predavati učenje o moralu, najprije u Zagrebu na Katehetskom institutu (1968. - 1974.), a potom i u Rijeci na Visokoj teološkoj školi (1974. - 1988.). Uz profesorsku službu, obnašao je i druge službe u svojoj Provinciji franjevaca trećoredaca glagoljaša: bio je duhovnik bogoslova, odgojitelj, ravnatelj trećoredske gimnazije i profesor u Odri, gvardijan u Odri i Rijeci, generalni vizitator provincije, višegodišnji član uprave i zamjenik provincijala, delegat na kapitulu Reda. Osim toga, bio je aktivan i na drugim poljima rada kao propovjednik, pučki misionar, voditelj duhovnih vježbi i obnova, duhovnik riječke bogoslovije, član Svećeničkog vijeća u Zagrebu i Rijeci. ${ }^{2}$

Najveću zadaću i odgovornost prihvaća u trenutku kad ga papa Ivan Pavao II. imenuje šibenskim biskupom 7. prosinca 1987. Zaređen je u Rimu 6. siječnja 1988., a upravljanje Šibenskom biskupijom preuzeo je 24. siječnja iste godine. Iznenada je preminuo od srčanog udara u Zagrebu 17. rujna 1996.

No, ova kratka biografska skica ne bi imala smisla, niti važnosti ako bismo zanemarili kontekst vremena u kojemu je živio mons. Badurina. Tek iz razumijevanja konteksta jasnije izranja njegov lik i značenje kao duhovnog gorostasa, koji je, zahvaljujući življenju snagom vjere, bio kadar odgovoriti na izazove koji su bili pred njim. Rođen je u doba Jugoslavije kao hrvatski sin na dalmatinskom škoju, kad su dobrim dijelom Dalmacije upravljali Talijani. Kao dječak pratio je ratna razaranja i poratna stradanja svoga naroda. Iako se nalazio u dobi u kojoj još nije mogao iznijeti svoj sud o Nezavisnoj Državi Hrvatskoj, bio je vrlo svjestan bezbožnog komunističkog režima, koji je sustavno zatirao vjerničku dušu njegova naroda. Upravo u takvom okruženju i ozračju proveo je najveći dio svojeg redovničkog i svećeničkog života, kao i prve dvije godine biskupske službe. Slobodnoj hrvatskoj državi, stvorenoj 1990., nakon raspada SFRJ-a, nije se imao kad ni radovati jer je već godinu dana kasnije započeo nametnut krvavi rat, u kojem je dobar dio Šibenske biskupije razoren, te je u godini nakon rata (od

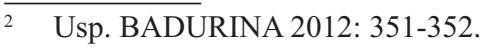


ljeta 1995. do ljeta 1996.) trebalo zacjeljivati rane žrtava i sanirati ratom razrušena područja. Tek kad se, uz gore spomenute kronološke i životopisne činjenice, ukaže na ove događaje kao na okvir u koji se smješta njegova osoba i život, postaje mnogo jasnije čemu je sve bio izložen tijekom cijeloga svoga života. U svjetlu tih saznanja može se mnogo bolje spoznati koliku su težinu imali njegov život i djelatnost te se nakon zadanog okvira može prijeći na teološku analizu navedenih bitnih pojmova određenih naslovom.

\section{Znak i svjedok vjere}

Kako bi se moglo ukazati na svjedočansku znakovitost vjere mons. Badurine, najprije valja propitati teološko značenje samoga pojma vjere. Vjerom se smatra međuosoban odnos povjerenja, s time da, kad se govori o kršćanskoj vjeri, treba znati kako je Bog predmet vjere: on je onaj o kojem se vjeruje, u koga se vjeruje i kojem se vjeruje. Vjera je ujedno i ljudski čin prihvaćanja Božje objave, stoga bi se iz perspektive moralne teologije reklo da je riječ o kreposti i habitusu, te kao takva ima i intelektualnu sastavnicu, u čijem ju se svjetlu najčešće i promatra. ${ }^{3}$

Primjenjujući na mons. Badurinu ono što je rečeno u definiciji vjere, može se reći da je cijelo njegovo postojanje bilo prožeto osjećajem i nadahnuto sadržajem vjere. No, budući da bi bilo neizvedivo sve to izložiti u jednom znanstvenom radu, neophodno je ograničiti se samo na ona mjesta gdje postoji njegovo izravno promišljanje o vjeri. Iz njegovih će se razmišljanja moći razlučiti kakvo je njegovo intelektualno-teološko poimanje vjere, ali i što mu je vjera značila u praksi. Kad se dublje iščitavaju njegovi tekstovi, postaje razvidno kako je, uz sve intelektualne informacije o značenju vjere, biskup usredotočen na ono živo i življeno iskustvo Boga, koje se prima po vjeri i čijom se snagom jedino može biti znak i svjedok vjere u svijetu.

Polazeći potom od konkretnosti čina vjere, mons. Badurina ističe središnju ulogu vjere u Krista Gospodina i velike vezanosti za njega i njegovu stvar. ${ }^{4}$ Od početka svoje biskupske službe inzistira stoga na sadržajima na kojima je i Gospodin Isus inzistirao kad je započeo svoje javno djelovanje, a to je vjera i obraćenje: „Ispunilo se vrijeme, približilo se kraljevstvo Božje! Obratite se i vjerujte evanđelju!“ (Mk $1,15)^{5}$. U nastupnoj homiliji, prisjetivši se i apostolâ i učenikâ, koji su povjerovali i osvjedočili se da Isus jest Krist, tumačeći svoj biskupski grb, usmjerio je svu

\footnotetext{
3 Usp. RAHNER I VORGRIMLER 1998: 252-253. Poput ovog rječnika (usp. str. 252-260), i drugi teološki rječnici vrlo iscrpno govore o razvoju ovog pojma te o mnogostrukosti dimenzija i značenja (usp. BOF 1988: 509-529; ARDUSSO 2002: 644-666).

4 Usp. BADURINA 1989: 20.

5 Isto: $14,16$.
} 
svoju pozornost na Gospodina Isusa, zaglavni kamen svih kršćanskih uvjerenja i cijeloga života: „Na grbu su grane masline. One simboliziraju Kristov mir: poziv na pomirenje s Bogom, na pomirenje među ljudima u privatnom životu, poziv na pomirenje u javnom, političkom životu što ga danas Crkva razglašava, proizlazi iz logike vjerovanja u Isusa Mesiju, koji je mir naš“ ${ }^{6}{ }^{6}$ Krist je važan jer je zaglavni kamen vjere u kojoj se i on sam, poput tolikih naraštaja vjernika, prepoznaje kršćaninom. A kršćani su kršćani upravo zato što vjeruju Kristu i u Krista, to jest kako za njih kaže i latinska riječ, da su christifideles, Kristovi vjernici. ${ }^{7}$

Osim Krista Gospodina, koji je temelj vjere, mons. Badurina često apostrofira ulogu Blažene Djevice Marije, kao uzora Crkve i vjernika, prethodnice na putu vjere ${ }^{8}$, ističući kako je ona znala prihvatiti Krista kao mir te je bila ispunjena njegovim mirom, duboko vjerujući da je on Isus Mesija, iščekivanje naroda. ${ }^{9} \mathrm{U}$ jednoj propovijedi na Trsatu rekao je sljedeće: „Ne, mi nismo pobjegli od života, nego nosimo u sebi vjeru koju smo dužni ovdje napojiti, koju smo dužni ovdje produbiti, koju smo došli ovdje prosvijetliti da bi ta vjera otkrila još dublje, još bolje smisao našega ljudskog postojanja, smisao naših zadataka, smisao naših životnih odgovornosti. Došli smo u jedno ozračje koje ostvaruje Marija, Marijina osoba, sa svom svojom snagom i veličinom. ${ }^{\text {" }}{ }^{10}$ Naravno, upravo Marija uznesena na nebo svakom vjerniku sjaji kako bi dublje doživio bogatstvo svoje vjere te iz njegovih riječi iščitavamo kako Marija radikalno svjedoči o potrebi da s Bogom koračamo ovim svijetom, koji je, između ostaloga, bezbožan svijet, jer bismo u protivnom bili siromašni, gladni i izgubljeni. ${ }^{11}$

6 Isto: 15 . Ove riječi, izgovorene u siječnju 1988., doista zvuče višestruko proročki. Osim što je $\mathrm{u}$ to doba bilo proročki govoriti o političkom miru koji daje Krist, mons. Badurina kao da je slutio krvavi scenarij koji se spremao i koji će uzeti svoj danak u Republici Hrvatskoj i među hrvatskim narodom.

7 Usp. BADURINA 2012: 67.

8 Usp. Isto: 14.

9 Usp. Isto: 16.

10 Isto: 118. I u nastavku propovijedi (str. 119-120) mons. Badurina govorit će o vjeri koja osvjetljuje smisao svega što je ljudsko, svega što čovjek jest i što svojim radom stvara na ovom svijetu. Zato je držao da su vjernici postavljeni u temelj, odnosno u korijen društva te se nemaju pravo izuzimati od te odgovornosti. Oni u biti po vjeri posjeduju Boga, to najveće čovjekovo blago, ali ga posjeduju kao Boga živoga za život svijeta. Upravo zato što je vjera život s Bogom i za Boga, vjernici se ne smiju osjećati pokunjenima, niti se povući u privatan kut. Naprotiv, svojim bi svjedočenjem u javnom životu trebali ostaviti tragove vjere i Evanđelja.

11 BADURINA 1989: 119: „Jest, ako večeras uspijemo dublje doživjeti bogatstvo svoje vjere koja nam sja u Mariji uznesenoj na nebo, ako uspijemo osvijetliti kako bismo bili siromašni, kako bismo bili gladni, kako bismo bili izgubljeni - ponavljam još jedanput - kako bismo bili sirote bez Boga u svijetu, kad bismo se bez otpora predali atmosferi bezboštva koja nas okružuje i koju udišemo nekada i protiv svoje volje; ako večeras doživimo da ćemo tek vjerom svladati to ograničenje, to omeđenje, to osiromašenje i zarobljenje svoga bića, onda ćemo tek postati svjesni koliko treba da smo radosni, koliko treba da smo ponosni, koliko treba da budemo odgovorni za Evanđelje Kristovo, za sebe i za sve ostale koji danas žive za naše društvo, za sve naše sugrađane.“ 
Drugi biblijski ideal vjere u kojem se mons. Badurina nastoji pronaći jest sveti Petar apostol, koji ispovijeda vjeru u Krista izravnom vjeroispoviješću, u čemu otkriva bit vjere: „I moglo mu je nekakvo poznavanje Biblije 'objaviti' da će doći Mesija. Ali to spojiti u 'Ti si Krist', to je vjera, to je dar Božji, i to je misterij."12 Time mons. Badurina prepoznaje osobnu dimenziju vjere kao bitnu dimenziju po kojoj se vjera razlikuje od religije te nije nastala razvojem nekih ideja, nego objavom Boga živoga po svome Sinu, na što se referirao i mons. Badurina.

No, mons. Badurina isto tako vrlo dobro uočava da bîti vjere prije svega pripada određena pasivnost, to jest primanje od Boga, nakon čega može uslijediti aktivnost. Zato je mišljenja da u pokušajima utemeljenja vjere čovjek može, doduše, poći od sebe i svoga razmišljanja: ja vjerujem, ja ljubim, ja se ufam. Međutim, postoji mnogo prikladniji i ispravniji put, kako nam i sâm svjedoči, ukazujući na Božji primat kad je u pitanju vjera: „Ali ja radije razmišljam drugačije: prije nego počnem rečenicu u kojoj je subjekt 'ja', nešto se je već dogodilo: ja sam ljubljen, meni je najprije iskazana ljubav, prema meni je učinjen neki korak, onda sam tek sposoban... Treba se najprije postaviti pasivno, u smislu 'primalački', a onda mi je vjera, odnosno povjerenje darovano, ili nije. "'13 Slijedom toga, mons. Badurina rado ističe da je takav primalački odnos vjere temelj unutarnjeg dinamizma i postaje doživljeno iskustvo, što može imati i dramatične tonove, pogotovo kad se čovjek suočava sa strahom da možda vjerom zavarava sebe ili da nije u pravu u odnosu na druge, koji imaju drukčija uvjerenja: „Čovjek se onda mora tako postaviti da sebi i drugima obrazloži što to znači 'iz vjere'. To je trajni proces obračunavanja, razračunavanja, odnosno te napetosti koja ne da mirno reći 'vjerujem' i gotovo, nego, uvijek je to u pitanju, uvijek je to u procesu, uvijek je to u produbljivanju. ${ }^{\text {"14 }}$

Ovdje je bitno istaknuti da to kaže onaj koji je bio profesor moralnog bogoslovlja te dobro poznaje da je, prema definiciji, vjera ljudski kreposni čin, no on ističe kako je prije svega Božji čin davanja, a ljudski čin primanja. Nadalje, to kaže čovjek koji je intelektualac i zna da je vjera i razumski čin, ali ne naglašava primat ljudskog razuma, što je sasvim ispravno. Tako vidimo da on razumijevanje vjere ne crpi iz nekog udžbenika ili pukog racionalnog razmišljanja ili stava, nego iz iskustva živoga Boga, koji se na poseban način približio te se dao osjetiti živim po svome Sinu Isusu Kristu i našem uskrsnulom Gospodinu. Premda je bio profesor moralne teologije, nije bio moralizator, niti je bio sklon moraliziranju. U kontekstu moralnih traženja i izbora drži da vjera ima „majeutičnu“ ulogu jer pomaže ljudima da lakše pronađu ono što je i onako u načelu nadohvat njihovih

\section{BADURINA 1989: 24.}

3 Isto: 25.

14 Na istome mjestu. Mons. Badurina naglašava da takva obrana nije apstraktna ni prema oblacima, nego prema konkretnim mentalitetima, idejama, udžbenicima, televiziji, izjavama političara, običnim ljudima itd. 
sposobnosti: „Teolozi i jedne i druge tendencije slažu se da vjera donosi opći nutarnji smisao, novi horizont, temeljnu usmjerenost, konačni cilj, internacionalnost humanom projektu čovjekovu."15

U konačnici, od riječi mons. Badurine može se stvoriti i oblikovati zaključak, iz kojeg je razvidna nezamjenjiva uloga vjere u životu čovjeka: „Kršćanska vjera je dar. Ona je pomoć da se bolje vidi svijet, život, smisao i kretanje, da se procjenjuju stvari i lakše nađe životna orijentacija. Kršćanska vjera nije opterećenje nego krila kojima se čovjek kreće kroz život, kroz povijest. “16 Naravno, vjera ne isključuje djela, kako se često u nekadašnjem sustavu znalo predbacivati vjernicima, nego ih, naprotiv, potencira. Upravo zbog svoje upućenosti na Boga i svoga zajedništva s njime, ljudska djela stječu kvalifikaciju moralnosti, koja je nerazumljiva bez vjere, kojom se uzvraća na objavu Božju: „Otkrivajući čovjeku smisao njega samoga i njegova djela, objava vraća stvorenju njegovo prvotno dostojanstvo uvodeći ga u intimnost s Bogom. Otvorenost prema pozivu 'biti više', do punine čije su granice nedohvatljive, $u$ vjeri dobiva nadopunu i određenje svoga značenja. Vjera nam otkriva da je čovjekova aktivnost odgovor Bogu. “17

No, gledajući potom na vjeru kao na čin, ona je čin čovjeka. Oni koji vjeruju zovu se vjernicima, ali ne primaju vjeru na privatan način, nego u zajednici koju je utemeljio Bog te je stoga povlašteno mjesto vjere Crkva kao narod Božji ${ }^{18}$, prihvatiteljica i čuvarica vjere. Tako vjera nije privatna datost, premda je osobna, a time je ujedno i pitanje zajednice Crkve, to jest Božje obitelji. Stoga, kad govori o vjeri Crkve i puka Božjega, zna se koristiti biblijskim sintagmama, kao što je 'vjerni ostatak' ${ }^{19}$, pokazujući da je glavno obilježje vjernika vjerovati u Boga, s time da je riječ o ostatku koji istinski drži do vjere u Boga, što i svojim ponašanjem odražava. U tom duhu mons. Badurina sebe ne smatra većim ili izuzetim od vjere naroda, nego veli da najprije mora biti učenik kako bi bio učitelj. Na tom je putu biskupu ,u mnogim stvarima učitelj i Božji narod, zajednička vjera - sensus fidelium, ono što egzistencijalno živi u ljudima. To nije vjera na razini intelektualne formulacije nego na razini doživljaja: život, smrt, rad, seljenje, brak, djeca, ljutnja, radost..."20

$\overline{15}$ BADURINA 1989: 103.

16 Isto: 28. Vidi i: Isti 2012: 123, gdje biskup govori o doprinosu Crkve u izgradnji boljeg i humanijeg svijeta.

17 BADURINA 1989: 83. Tako aktivnost dobrih djela nastaje kao čovjekov odgovor Bogu, nakon što je čovjek bio 'pasivan' tijekom primanja dara vjere, što je već prije istaknuto.

18 BADURINA 1989: 27: „Da bi se crkvenost razvijala, da bi ostvarila ono za što postoji u povijesti, ona svakako treba da nađe svoje izvore i svoj izvorni način samoshvaćanja i artikuliranja, postojanja, a to svakako mora početi od toga da su svi - po vjeri i krštenju uključeni u Crkvu - jedno, jednaki, jedna zajednica, Božji narod.“ 


\section{Znak i svjedok vremena}

Uz spomenuto značenje vjere za mons. Badurinu, valja sada pokazati kako je on bio i znak u svome vremenu i u svojoj službi. No, prije svega dužnost je ukazati na njegovo teološko poimanje znakova vremena jer uopće nije bila rijetkost da mons. Badurina govori o znakovima vremena. To je činio u duhu koncilskog nauka, pokušavajući i sam biti aktualan i vjeran crkvenim dokumentima. Jednim od najvažnijih znakova vremena smatrao je to što svjetsko javno mnijenje usvaja vrednote osobe kao uporište i nadu za humaniji svijet. Osim toga, smatrao je da sve znakove Crkva treba ispitivati i tumačiti u svjetlu Evanđelja ${ }^{21}$, po čemu ga onda možemo nazvati i svjedokom vremena.

Jedan od znakova vremena za Crkvu bio je događaj Drugog vatikanskog sabora. Mons. Badurina kao svjedok vjere predstavljao je istinski znak vremena jer je bio koncilski čovjek od prvih dana koncila. On je još kao mladi svećenik i redovnik imao puno povjerenje u koncilske oce, preko čijeg je djelovanja Duh Sveti želio dati poticaj Crkvi i novi vjetar u jedra njezinih nastojanja dok brodi morem ovoga svijeta. Budno je pratio sva zbivanja na koncilu i oko koncila te je oduševljeno prihvatio koncilske smjernice, natapajući svoje tekstove i razmišljanja koncilskim dokumentima, koje je pozorno čitao i kojima je potkrepljivao svoja teološka promišljanja. Mons. Badurina znao je da Crkva mora najprije ponirati u sebe i biti svjesna svoga identiteta, ali se nije mogla zadovoljiti življenjem samo za sebe i u sebi, nego je trebala tražiti dijalog i susret sa svijetom ili, kako kaže, treba graditi mostove preko provalije koja se stvorila, osobito u posljednjim dvama - trima stoljećima laicizacije i emancipacije zapadne kulture. ${ }^{22}$

Osim toga, bio je uvjeren kako redovništvo, kao duhovna snaga Crkve i ures njezine ljepote, treba biti osjetljivo na znakove vremena. ${ }^{23}$ Očito svjestan karizmatske snage redovništva te potpune predanosti i upućenosti na Krista Gospodina, držao je da bi redovnici, ako žele ispravno ispuniti svoje poslanje u Crkvi, trebali znati čitati znakove vremena. ${ }^{24}$

Prelazeći potom na konkretnu praksu života, mons. Badurina govori o mirovnim pokretima kao o znaku vremena. ${ }^{25}$ No, ako je mirotvorstvo jedan od prepoznat-

21 Usp. Isto: 71. Na drugome mjestu (str. 157) mons. Srećko ustvrdit će da je ispitivanje znakova vremena locus theologicus za prihvaćanje svakog kairosa, čineći prisutnim i djelatnim kraljevstvo Božje. Drugi je koristan tekst: BADURINA 2012: 123.

22 Usp. Isti 1989: 155.

23 Isto: 150

24 Zanimljivo je kako za redovnike, na tragu Sabora, tvrdi da trebaju ući u dijalog sa svijetom, umjesto da se priklone jednostranom odbacivanju svijeta, kao što je nekada sugerirala redovnička duhovnost (usp. BADURINA 1989: 162-175.)

25 Usp. Isto: 108-112. 
ljivih znakova vremena, onda taj znak treba primijeniti i na njega jer je on doista bio mirotvorac, pogotovo u vrijeme ratnih razaranja tijekom Domovinskoga rata, zauzimajući se za istinski mir u okolnostima svoje službe. Svim čimbenicima nemira znao je otvoreno pisati te ih upozoravati: srpskim vođama uputio je upit tko je naoružao tolike srpske civile koji su se spremili za rat te tko će snositi posljedice toga ${ }^{26}$; u pismu odaslanom Međunarodnoj zajednici prosvjedovao je zato što ne čini dovoljno za uspostavljanje mira te mu onemogućuje vršenje biskupske službe na okupiranim teritorijima.

U pojave suvremenog vremena ubraja se i ateizam, čemu je i Drugi vatikanski sabor posvetio posebnu pozornost, a zbog pogibelji koju je širio bilo je prijeko potrebno dati odgovor ateističkoj kulturi. ${ }^{27}$ Mons. Badurina nije o ateizmu znao samo određene filozofsko-teološke teorije, nego je živio u društvu u kojem je ateizam bio ideološki nametnut kao religija režima i partije. Smatrao ga je velikom pošasti, koja pustoši duše pojedinaca, a nesagledivu štetu nanosi cijelim narodima te ga je Crkva s pravom uzela u razmatranje kao svojevrstan znak vremena, premda ateizam nije bio znak koji obećava i donosi dobrobit čovjeku i čovječanstvu, nego, naprotiv, bio je to prijeteći znak. Međutim, uz štetnost ideološkog ateizma, bilo je jasno da je poguban onaj praktični, o čemu mons. Badurina jasno govori: „No i nije najizazovnije i najteže opterećenje za vjernika službeni ateizam koji se deklarira na političkim govornicama, nego onaj koji je ušao u život ljudi, u srce ljudi, onaj praktični, svakidašnji indiferentizam, koji me pita što je $s$ tom religioznom pretpostavkom čovjeka, s onim 'anima humana naturaliter christiana' (Tertulijan)?“28.

Mons. Badurina nikad se nije mirio s nepravednim stanjem koje je vladalo $\mathrm{u}$ ondašnjem komunističkom društvu te je jasno dizao svoj glas protiv surove i izopačene ideološke diskriminacije, koja se provodila protiv vjere i vjernika. Premda nije zagovarao revolucije, zauzeo je sasvim jasan i dosljedan stav, prema kojemu je očekivao poštovanje svačijih prava, a da pri tome nitko ne bude ugrožen: „Tako niti prava nekih ljudi koji ne vjeruju ne smiju biti tako proširena da ugrožavaju prava drugih, kao što ni prava vjernika ne smiju ugrožavati prava onih koji drugačije misle. " ${ }^{\text {29 }}$ Kao dobar analitičar i misaon čovjek, biskup je znao da se u komunističkom režimu stvarala umjetna pregrada između Crkve i građanskog života, što je potom, kao posljedica toga, rezultiralo rascjepom u samom čovjeku između vjernika i građanina. ${ }^{30}$ Kao Hrvat i katolik, bio je ponosan na doprinos

\footnotetext{
$\overline{26}$ Usp. Isti 2012: 213. Radi se o otvorenom pismu vođama naroda iz 1990. ili 1991.

27 Usp. BADURINA 1989: 124.

28 Isto: 25 .

29 Isto: 36

30 Usp. Isti 2012: 80. Naravno da je bilo poželjno dosljedno artikuliranje ovog problema i življenje osobnosti.
} 
žive vjere u Boga u povijesti hrvatskog naroda te je, slijedom toga, apelirao na tu zlatnu nit, o kojoj su ovisili život i budućnost samoga naroda. ${ }^{31}$

Nadalje, mons. Badurina bio je izravni svjedok tragedije, kako je sebe defini$\mathrm{rao}^{32}$, koja je u novije doba pogodila Crkvu u Hrvatskoj i hrvatski narod, iz kojeg je potekao. Kao takav, uvijek je isticao, u duhu dijaloga koji je trebalo voditi u društvu, istinski doprinos koji vjernici i Crkva daju zajednici te je na temelju toga tražio da se Crkvi dopusti pravo na javnost u društvu. ${ }^{33} \mathrm{U}$ takvom društvu trebalo je svjedočiti da vjera u Boga nije otuđenje čovjeka od njegove bîti, nego, dapače, da se otuđujući od Boga čovjek otuđuje od sebe. ${ }^{34} \mathrm{U}$ tragediji Domovinskog rata uvijek je isticao načela humanosti i pravednosti, kao i neophodnost humanosti i jednakosti prema svima koji su u nevolji, što su jasni evanđeoski principi. ${ }^{35}$

\section{Zaključak}

Iz spomenutoga sasvim je razvidno kako je mons. Srećko Badurina, biskup i franjevac trećoredac, doista bio svijetao lik ne samo provincije franjevaca trećoredaca glagoljaša, nego i cijele Crkve u Hrvata potkraj dvadesetoga stoljeća. Premda nije poživio toliko dugo da kronološki uđe u treće tisućljeće kršćanstva, ipak je, po svom svetom i kreposnom životu, ispred nas jer je bio pogleda uprta u Krista i vječnost te je imao ne samo jasne i nedvosmislene principe, nego i prava uporišta života. Njegov primjer ostaje franjevcima trećorecima, ali isto tako i svima koji traže autentične neprolazne znakove kao putokaze. U tome im čovjek vjere poput Srećka može biti dragocjena pomoć i usmjerenje.

\footnotetext{
31 Usp. BADURINA 2012: 115-117.

32 Usp. Isto: 35.

33 Usp. Isto: 49, 118.

34 Usp. Isto: 123. Ovaj je govor izrečen u siječnju 1990., kad se već osjećao dah slobode i demokratizacije društva na osnovi poštivanja ljudskih prava, te je biskup govorio o potrebi da se svi oslobode državnog ateizma, za što je potrebna istinska duhovna katarza i oslobođenje.

35 Usp. BADURINA 2012: 72.
} 


\section{Bibliografija}

ARDUSSO, Franco. 2002. Fede. U Teologia, ur. Giuseppe Barbaglio, Giampiero Bof, Severino Dianich, 644-666. Milano: San Paolo.

BADURINA, Srećko. 1989. Prema novoj zrelosti. Zagreb: Kršćanska sadašnjost, Provincijalat franjevaca trećoredaca.

BADURINA, Srećko. 2012. Stopama pastira. Sabrao i uredio fra Antun Badurina. Šibenik-Zagreb: Šibenska biskupija.

BOF, Giampiero. 1988. Fede. U Nuovo dizionario di teologia, ur. Giuseppe Barbaglio, Severino Dianich, 509-529. Milano: San Paolo.

RAHNER, Karl, Herbert VORGRIMLER. 1998. Fede. U Dizionario di Teologia ${ }^{5}$, 252253. Milano: TEA.

\section{Srećko Badurina (1930 - 1996), vescovo del terzo ordine francescano, testimone della fede e segno del tempo}

L'autore in questo articolo ha fatto un' indagine sulla persona e l'operato di Srećko Badurina (1930 - 1996), francescano del Terzo ordine e poi vescovo di Sebenico in Croazia il quale ha segnato una traccia profonda nella storia della Chiesa in Croazia nella seconda metà del XX secolo. Per mettere meglio in rilievo l'importanza che ebbe mons. Badurina come vero testimone della fede, nel tempo in cui visse, la ricerca è divisa in tre parti. Nella prima parte era indispensabile disegnare per sommi capi il quadro della sua vita perché solo grazie all'esatto contesto storico e alla giusta cronologia degli eventi in cui qualcuno ha vissuto, può essere spiegato il percorso della sua vita e può essere capita l'importanza della sua testimonianza. Già da bambino e da ragazzo ha avuto una ricca esperienza della situazione del proprio popolo che in parte era sotto l'occupazione italiana e in parte apparteneva alla Jugoslavia dominata in prevalenza dai serbi. Ha fatto poi esperienza della tragedia della Seconda guerra mondiale e in seguito del regime comunista che si sforzava di trasformare l'intera società in uno stato ateo.

Sullo sfondo di questo quadro storico l'autore prosegue la ricerca su due piani dispiegandola in due capitoli conseguenti. Dapprima esamina, a partire dagli scritti raccolti in alcuni volumi, quale concetto di fede teologale possiede mons. Badurina e quali sono i principali accenti da lui posti in diverse problematiche nelle quali si è trovato il mondo e l'uomo odierno. Dal contesto concreto con più chiarezza si ravvisa la sua importanza di autorevole testimone della fede nella seconda metà del secolo XX. Soprattutto va messo in rilievo il suo atteggiamento profetico nei confronti del comunismo e la convinzione che i fedeli devono dare un contributo specifico allo sviluppo della medesima. I christifideles si impegnano e con le proprie opere contribuiscono al bene della società e le loro speranze escatologiche 
non diminuiscono, ma accrescono il loro impegno nel tempo. Allo stesso modo contro coloro che disprezzavano la fede e i fedeli in quella società, Badurina dimostra che l'atto di fede è una realtà intellettuale ed è autenticamente umano.

Nella terza parte la ricerca verte sul concetto del segno dei tempi promosso dal Concilio vaticano secondo. L'autore afferma che mons. Badurina seppe cogliere le sfide che il Concilio Vaticano II ha lanciato alla Chiesa. Prima di tutto perché con la vita da pastore irreprensibile, essendo un valido testimone della fede, è diventato il segno del suo tempo, sia durante il periodo del comunismo, sia durante la recente guerra di cui è stato vittima il popolo croato dal 1991 al 1995. Mons. Badurina è stato testimone valido della riforma del Vaticano II di cui ha protetto e promosso l'autentica dottrina sia al livello teologico-speculativo che pastorale. Ha ritenuto sempre che proprio il Concilio fu un grande segno che la Chiesa del tempo moderno avrebbe dovuto cogliere con coraggio nell'obbedienza allo Spirito Santo. Poi a partire dalla dottrina conciliare ha saputo valutare in maniera esatta anche la vita religiosa quale segno del tempo al quale la Chiesa, sempre, ha saputo contare ed esigere un' autentica testimonianza di fede. In quest'ottica dei segni del tempo il vescovo Badurina ha saputo valutare anche l'ateismo dalle cui apparenze non si è lasciato mai ingannare, ma anche il pacifismo come fenomeno del nostro mondo e tempo. Egli si è sempre sforzato per le soluzioni giuste nei conflitti che distruggevano la sua patria, ma questo non gli impediva di affermare che la pace è frutto della giustizia. In tal senso non si è mai scoraggiato nel dire la verità $\mathrm{e}$ nel vivere secondo gli autentici principi evangelici.

\section{Srećko Badurina (1930 - 1996), Bishop-Tertiary, Witness of Faith and Sign of Time}

This paper surveys life and work of Srećko Badurina (1930 - 1996), a Third Order Franciscan and later bishop of Šibenik in Croatia who left a deep mark in the history of the Church in Croatia in the second half of the twentieth century. As to better stress the importance that Msgr. Badurina had, as a true witness of the faith, in the time in which he lived, the study is divided into three parts. In the first part it has been essential to briefly illustrate his life because only thanks to the exact historical context and the correct chronology of events that someone lived through the path of their life can be explained and the importance of their testimony can be understood. As a child and as a boy he had a rich experience of the situation of his people who were in part under the Italian occupation and partly belonged to Yugoslavia that was dominated mainly by Serbs. He then experienced the tragedy of the WWII and later the communist regime that tried to transform the whole society into an atheist state. 
Against the background of this historical picture the study continues on two levels that are unfolded in two subsequent chapters. First, based on his writings collected in several volumes, the concept of Msgr. Badurina's theological faith and the main accents which he placed regarding various problems of modern world and modern man are examined. From this concrete context his importance as an authoritative witness to the faith in the second half of the twentieth century becomes more clear. His prophetic stance against communism and the conviction that the faithful should make a specific contribution to its development should be emphasized. The christifideles go about to contribute with their work to the good of society and their eschatological hopes do not diminish but increase their commitment over time. Similarly, being against those who despised the faith and the faithful in the society, Badurina has shown that the act of faith is an intellectual reality and is authentically human.

In the third part the study focuses on the concept of the Sign of the Times promoted by the Second Vatican Council. The paper shows that Msgr. Badurina was able to meet the challenges that the Second Vatican Council set before the Church. First of all, due to his impeccable pastoral life, he became an effective witness of the faith and a sign of his time, both during the communist period and during the recent war from 1991 to 1995 in which the Croatian people was a victim. Mgr. Badurina was an effective witness to the reform of the Second Vatican Council which has protected and promoted the true doctrine both on theological-speculative and pastoral levels. He always felt that the Council was just a great sign that the Church of modern times should seize courageously in obedience to the Holy Spirit. Starting from the Council's doctrine he was able to assess accurately even the religious life as a sign of the time in which the Church always knew how to reckon with and require an authentic testimony of faith. In the view of these signs of the time, Bishop Badurina was able to evaluate not only atheism by whose appearances he never let himself be deceived, but also pacifism as phenomena of our world and time. He always strived for just solutions in the conflicts that were destroying his homeland, but this did not prevent him to say that peace was the result of justice. In this sense, he never discouraged from telling the truth and living according to the true principles of the gospel.

Parole chiavi: Srećko Badurina, fede, segno del tempo, Concilio Vaticano II, ateismo, pacifismo

Key words: Srećko Badurina, faith, sign of time, Second Vatican Council, atheism, pacifism

Ključne riječi: Srećko Badurina, vjera, znak vremena, Drugi vatikanski sabor, ateizam, mirotvorstvo

Ivan Bodrožić

Katolički bogoslovni fakultet Sveučilišta u Zagrebu

HR-10000 Zagreb, Vlaška ulica 38

ivan.bodrozic@gmail.com 


\section{FILOZOFSKI FAKULTET SVEUČILIŠTA U ZAGREBU \\ ZAVOD ZA HRVATSKU POVIJEST \\ INSTITUTE OF CROATIAN HISTORY \\ INSTITUT FÜR KROATISCHE GESCHICHTE}
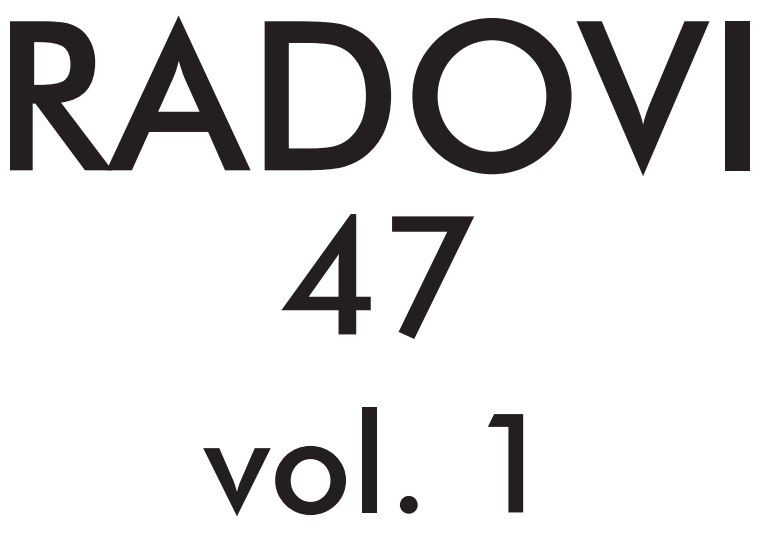

ZAVOD ZA HRVATSKU POVIJEST

FILOZOFSKOGA FAKULTETA SVEUČILIŠTA U ZAGREBU

\section{PF press \\ ZAGREB 2015.}




\title{
RADOVI ZAVODA ZA HRVATSKU POVIJEST FILOZOFSKOGA FAKULTETA SVEUČILIŠTA U ZAGREBU
}

\author{
Knjiga 47, vol. 1
}

\author{
Izdavač / Publisher \\ Zavod za hrvatsku povijest \\ Filozofskoga fakulteta Sveučilišta u Zagrebu \\ FF-press \\ Za izdavača / For Publisher \\ Vlatko Previšić \\ Glavni urednik / Editor-in-Chief \\ Hrvoje Gračanin \\ Izvršna urednica / Executive Editor \\ Inga Vilogorac Brčić \\ Uredništvo / Editorial Board
}

Bruna Kuntić-Makvić (stara povijest/ancient history), Zrinka Nikolić Jakus (srednji vijek/ medieval history), Hrvoje Petrić (rani novi vijek/early modern history), Željko Holjevac (moderna povijest/modern history), Tvrtko Jakovina (suvremena povijest/contemporary history),

Silvija Pisk (mikrohistorija i zavičajna povijest/microhistory and local history),

Zrinka Blažević (teorija i metodologija povijesti/theory and methodology of history)

Međunarodno uredničko vijeće / International Editorial Council

Denis Alimov (Sankt Peterburg), Živko Andrijašević (Nikšić), Csaba Békés (Budapest), Rajko Bratož (Ljubljana), Snježana Buzov (Columbus, Ohio), Svetlozar Eldarov (Sofija), Toni Filiposki (Skopje), Aleksandar Fotić (Beograd), Vladan Gavrilović (Novi Sad), Alojz Ivanišević (Wien),

Egidio Ivetić (Padova), Husnija Kamberović (Sarajevo), Karl Kaser (Graz),

Irina Ognyanova (Sofija), Géza Pálffy (Budapest), Ioan-Aurel Pop (Cluj),

Nade Proeva (Skopje), Alexios Savvides (Kalamata), Vlada Stanković (Beograd), Ludwig Steindorff (Kiel), Peter Štih (Ljubljana)

Izvršna urednica za tuzemnu i inozemnu razmjenu / Executive Editor for Publications Exchange Kristina Milković

Tajnik uredništva / Editorial Board Assistant

Dejan Zadro

Adresa uredništva/Editorial Board address

Zavod za hrvatsku povijest, Filozofski fakultet Zagreb, Ivana Lučića 3, HR-10 000, Zagreb

Tel. ++385 (0)1 6120 150, 6120 158, faks ++385 (0)1 6156879

Časopis izlazi jedanput godišnje / The Journal is published once a year

Časopis je u digitalnom obliku dostupan na / The Journal in digital form is accessible at Portal znanstvenih časopisa Republike Hrvatske „Hrčak“ http://hrcak.srce.hr/radovi-zhp

Financijska potpora za tisak časopisa / The Journal is published with the support by

Ministarstvo znanosti, obrazovanja i športa Republike Hrvatske

Časopis je indeksiran u sljedećim bazama / The Journal is indexed in the following databases:

Directory of Open Access Journals, EBSCO, SCOPUS, ERIH PLUS 
Naslovna stranica

Iva Mandić

Grafičko oblikovanje i računalni slog

Marko Maraković

Lektura

Samanta Paronić

Tisak

Web2tisak, Zagreb

Naklada

250 primjeraka

Časopis je u digitalnom obliku dostupan na Portalu znanstvenih časopisa Republike Hrvatske ,Hrčak“ http://hrcak.srce.hr/radovi-zhp

The Journal is accessible in digital form at the Hrcak - Portal of scientific journals of Croatia http://hrcak.srce.hr/radovi-zhp 


\section{RADOVI 47}

\section{vol. 1}

ZaVoda za hrVAtSku poviJest FILOZOFskoga fakulteta SVeuČILIŠTA u Zagrebu 


\title{
Tematski blok / Themed issue
}

\section{TREĆOREDSKA GLAGOLJAŠKA TRADICIJA U EUROPSKOM KONTEKSTU TERTIARY GLAGOLITIC TRADITION IN EUROPEAN CONTEXT}

\author{
Radovi međunarodnoga znanstvenog skupa \\ održanoga 27. i 28. IX. 2013. na Hrvatskom katoličkom sveučilištu u Zagrebu \\ u organizaciji \\ Provincije franjevaca trećoredaca glagoljaša u Zagrebu, Hrvatskoga katoličkog \\ sveučilišta u Zagrebu, Filozofskoga fakulteta Sveučilišta u Zagrebu - Odsjek za \\ povijest, Filozofskoga fakulteta Sveučilišta u Splitu - Odsjek za povijest, Instituta \\ za povijest umjetnosti u Zagrebu i Staroslavenskoga instituta u Zagrebu \\ Proceedings of the International Scientific Conference \\ held on 27th and 28th September 2013 at the Catholic University of Croatia in Zagreb \\ and organized by \\ the Province of the Glagolitic Friars of the Third Order Regular, Catholic University \\ of Croatia in Zagreb, Faculty of Humanities and Social Sciences of the University \\ of Zagreb - Department of History, Faculty of Humanities and Social Sciences of \\ the University of Split - Department of History, Institute of Art History, \\ and Old Church Slavonic Institute
}

Gosti urednici / Guest editors

\author{
Ivan BOTICA \\ Tomislav GALOVIĆ \\ Kristijan KUHAR
}

